\title{
TINDAK TUTUR PUJIAN SISWA KELAS XI SMA NEGERI 1 TUTUK TOLU
}

\author{
Aisa Rumbati \\ Universitas Pattimura \\ e-mail: rumbatiaisya@gmail.com
}

\begin{abstract}
Abstrak: "Tindak Tutur Pujian Siswa Kelas XI SMA Negeri 1
Tutuk Tolu" Skripsi. Program Studi Bahasa dan Sastra Indonesia Universitas Pattimura. Penelitian ini dapat menggambarkan tentang tindak tutur pada siswa kelas XI SMA Negeri 1 Tutuk Tolu. peneliti ini menggunakan penelitian kualitatif untuk menggambarkan hal-hal pokok yang sesuai dengan permasalahan yang diteliti. Pengumpulan data dapat dilakukan melalui teknik wawancara, observasi, perekaman, dan dokomentasi. Sementara itu teknik analisis kualitatif bergerak dari pengumpulan data, reduksi data, penyajian data kemudian penarikan kesimpulan. Hasil penelitian di SMA Negerei 1 Tutuk Tolu, Kecamatan Tutuk Tolu, Kabupaten Seram Bagian Timur, ditemukan tuturan pujian dengan wujud, fungsi dan modus yang berbeda-beda yang menghasilkan tiga wujud verbal tuturan pujian di antaranya wujud deklaratif, wujud interogatif, dan wujud imperatif. Selain itu terdapat empat fungsi verbal yang ditemukan di antaranya fungsi peneriman, fungsi teguran, fungsi perintah, dan fungsi kritikan dengan modus tuturan langsung dan tuturan tidak langsung.

Kata Kunci: Bentuk Verbal, Fungsi, Modus.
\end{abstract}




\title{
SPEECH ACTS OF PRISE STUDENTS OF CLASS XI SMA NEGERI 1 TUTUK TOLU
}

\author{
Aisa Rumbati \\ Universitas Pattimura \\ e-mail: rumbatiaisya@gmail.com
}

\begin{abstract}
Speech Act Of Praise Students Of Class XI SMA Negeri 1 Tutuk Tolu" Thesis. Indonesian Language and Literature Faculty, Pattimura University. This research can describe speech acts in class XI students of SMA Negeri 1 Tutuk Tolu. This researcher will use qualitative research to illustrate the main points that are in accordance with the problem under study. Data collection can be done through interviews, observation, recording, and documentation. Meanwhile qualitative analysis techniques move from data collection, data reduction, data presentation then drawing conclusions. Research results at Negerei 1 Tutuk Tolu High School, Tutuk Tolu District, East Seram District, praise speech with different forms, functions and modes that produced three verbal forms of praise speech including declarative sentences or statement sentences, forms interrogative or question sentence, and imperative sentence or command sentence. In addition, there are four verbal functions found speech with different modes, including the function of the receiver (recognition / strength), the function of reprimand, function of commands, and functions of criticism.
\end{abstract}

Keywords: Form, Function, Modus. 


\section{A. PENDAHULUAN}

Bahasa merupakan alat yang digunakan dalam berkomunikasi yang dapat digunakan oleh manusia dengan anggota masyarakat lain. Bahasa itu berupa pikiran, keinginan, atau perasaan yang ada pada diri si penutur. Tuturan yang dapat disampaikan itu hendaklah dapat mendukung maksud secara jelas agar apa yang dipikirkan, diinginkan, atau dirasakan dapat diterima dengan baik. Sebagai alat komunikasi bahasa mampu menimbulkan adanya rasa saling memahami antara penutur dan mitra tutur, atau antara penulis dan juga pembaca. Bahasa dalam proses komunikasi dan berinteraksi sangat diperlukan oleh setiap manusia dalam segala bentuk kegiatannya. Oleh karena itu, bahasa merupakan media yang tidak dapat dilepaspisahkan dari manusia, sebab tanpa bahasa, manusia tidak dapat melakukan aktifitasnya secara normal.

Tindak tutur ditemukan sangat beragam bentuknya, terdapat banyak hal yang dibicarakan sesuai dengan kebutuhannya, seperti menyampaikan ide, mengekspresikan perasaan, menyampaikan informasi. Hal penting yang dapat diperoleh adalah maksud dari tuturan itu, apabila maksud dari tuturan itu dapat diterima dengan baik oleh mitra tutur, berarti tuturan itu berhasil disampaikan dengan baik dan tepat oleh penutur. Artinya tuturan tersebut dituturkan sesuai dengan konteks atau kondisi tuturan.

Proses pembelajaran di sekolah, guru dan siswa tentu terlibat dalam interaksi komunikasi. Interaksi terjadi karena adanya tuturan dari guru dan juga siswa, tanpa adanya tuturan, proses pembelajaran tidak akan berjalan sesuai dengan apa yang menjadi tujuan pencapaian pembelajaran. Dengan demikian, tuturan yang disampaikan beragam bentuknya, baik berupa informasi, pertanyaan, permintaan maaf, memohon, memberikan pujian dan lain sebagainya.

Seperti halnya pembelajaran di SMA Negeri 1 Tutuk Tolu, di dalam kelas baik dalam keadaan santai maupun dalam proses pembelajaran, guru dan siswa sering menggunakan tuturan-tuturan yang bersifat ekspresif yaitu dengan menggambarkan keadaan psikologi guru dan juga siswa tentang sesuatu, misalnya menyampaikan terima kasih, menyampaikan ucapan selamat, mengkritik, menyalahkan, mengeluh, dan memberikan pujian dan lain-lain. Tuturan-tuturan itu merupakan tuturan ekspresif. Dengan demikian peneliti memfokuskan penelitiannya pada tindak tutur pujian saja, karena tindak tutur pujian tidak hanya disampaikan begitu saja dalam bentuk kata-kata, tetapi penutur juga menyampaikan pujian tersebut berdasarkan sumbernya, tingkat ketulusannya, targetnya, ekspresinya dan juga bentuk tuturannya.

Sesuai dengan pengetahuan peneliti bahwa tuturan pujian sering didapatkan di lingkungan sekolah SMA Negeri 1 Tutuk Tolu baik di dalam kelas maupun di luar kelas. Tuturan pujian yang disampaikan guru kepada siswa merupakan hal yang biasa 
terjadi ketika proses pembelajaran berlangsung, tuturan pujian itu disampaikan guru kepada siswa tujuannya untuk memberikan respon positif untuk hasil kerjanya sekaligus sebagai penghargaan. Selain yang dituturkan guru kepada siswa, tuturan ini juga sering dituturkan siswa kepada guru, dan antar siswa satu dengan siswa yang lain ketika mengagumi sesuatu yang unik dari guru maupun siswa pada saat duduk santai ataupun dalam proses pembelajaran berlangsung.

Tindak pujian dalam komunikasi di sekolah menengah atas menunjukkan rasa hormat kepada siswa. Beberapa contoh pujian adalah "Bagus, Stevi seratus untukmu!", "Wah, hebat, Ana mendapat tempat pertama!", "Hah, kamu pintar!". Penggunaan kata-kata untuk memuji mengungkapkan kegembiraan guru dengan mengatakan (1) baik, (2) hebat, dan (3) rapi. Pertama, kata baik berarti bahwa guru puas dengan jawaban Stevi. Ini sejalan dengan konteks tindakan yang mengatakan bahwa pujian dapat diberikan ketika pertanyaan guru dijawab dengan benar oleh siswa. Kedua, pujian yang disampaikan dalam bentuk great menunjukkan kebanggaan guru atas prestasi siswa. Ketiga, penggunaan kata smart menyajikan bahwa guru ingin mengungkapkan kebahagiaannya kepada siswa yang pandai. (Pattiasina dkk, 2017:1316).

Selain mengandung perasaan yang sama, ketiga tindak tutur itu juga memiliki implikasi pragmatis. Dilihat dari konteks masing-masing tindak tutur, maka "Bagus, Stevi seratus untukmu! Menyiratkan bahwa guru berharap Stevi akan selalu belajar keras dan mencapai yang lebih baik di masa depan. Tindak tutur (2) tidak hanya berarti memuji dan memberi tahu bahwa Ana mendapat tempat pertama. Namun, tindak tutur ini berisi harapan guru pada siswa lain. Tindak tutur (3) menyiratkan bahwa guru berharap bahwa siswa dapat belajar lebih rajin dan terus meningkatkan strategi belajar mereka.

Terdapat tiga bahasa yang dipakai oleh siswa dan guru dalam lingkungan sekolah dalam bertutur, diantaranya Bahasa Indonesia yang biasanya digunakan dalam proses pembelajaran di dalam kelas, Selain itu bahasa Melayu Ambon dan Bahasa Geser yang biasanya digunakan dalam keadaan santai baik di dalam kelas maupun di luar kelas oleh guru maupun siswa.

Tindak tutur pujian, yaitu suatu tuturan yang bersifat positif dan menunjukkan ekspresi yang berupa evaluasi yang positif oleh penutur kepada mitra tutur. Tindak tutur pujian merupakan bagian dari tindak tutur ilokusi, karena tindak tutur pujian ini adalah salah satu fungsi dari penutur yang membentuk tuturan dengan beberapa fungsi di dalam pikiran, yang mengandung daya untuk melakukan tindakan tertentu dengan hubungan mengatakan atau menginformasikan sesuatu.

Tindak pujian sebagian besar digunakan untuk menyampaikan emosi pembicara. Emosi pembicara diekspresikan melalui pengungkapan sikap psikologis 
guru terhadap situasi yang tersirat dalam ilusi. Pujian adalah bagian dari tindakan ekspresif. Ini cenderung menunjukkan kegembiraan dan rasa hormat kepada siswa sebagai mitra berbicara guru, bahkan terkadang menghasilkan berlebihan. Guru wicara : "Biarkan saya melihat. Laporan yang brilian, semua nilai bagus ". Tindak tutur ini menggambarkan ekspresi kondisi psikologis guru yang mengagumkan. Bentuk pujian ekspresif yang disampaikan oleh guru secara lisan berarti bahwa dia terkesan dengan upaya siswa untuk menjaga nilainya tetap baik. Tindakan pujian mungkin membuat siswa merasa lebih percaya diri dengan dirinya sendiri.

Pentingnya tuturan pujian dalam pembelajaran bagi guru terhadap siswa, sebab tuturan pujian dilihat sebagai bentuk apresiasi kepada siswa dalam pempelajaran yang berupa kata-kata, klausa dan juga kalimat. Tuturan ini bertujuan untuk memberikan respon positif berupa pujian dalam menyemangati siswa yang aktif. Hal ini juga dilihat sebagai bentuk motivasi kepada siswa yang lain agar dapat menjadi seperti siswa yang mendapat pujian. Selanjutnya, untuk mengetahui pentingnya tuturan pujian di luar pembelajaran tentu juga ada, karena tuturan pujian sendiri dilihat sebagai bentuk respon positif yang tentu akan membuat keinginan semua orang ingin dipuji untuk berusaha menampilkan yang terbaik, sehingga dapat dikatakan bahwa tuturan pujian membawa perubahan dalam diri seseorang.

Penelitian ini berlokasi di SMA Negeri 1 Tutuk Tolu yang merupakan salah satu sekolah menengah atas negeri yang berada di Desa Danama, Kecamatan Tutuk Tolu, Kabupaten Seram Bagian Timur (SBT). Berdasarkan contoh dan alasan di atas maka, peneliti tertarik untuk meneliti tentang tindak tutur pujian siswa kelas XI SMA Negeri 1 Tutuk Tolu. Alasan peneliti memilih kelas XI sebagai sampel dari data-data yang akan dikumpulkan, karena siswa-siswi yang ada di dalam kelas XI merupakan kelas yang berproses menuju kematangan sehingga emosi mereka cenderung labil, dan kemungkinan akan berpengaruh juga terhadap tindak tutur pujian mereka. Penelitian ini bertujuan untuk mendeskripsikan tindak tutur pujian siswa kelas XI SMA Negeri 1 Tutuk Tolu.

Levinson dalam (Kunjana, 2005:48) mendefinisikan pragmatik sebagai studi bahasa yang mempelajari relasi bahasa dengan konteksnya. Konteks yang dimaksud tergramatisasi dan terkodifikasi sehingga tidak dapat dilepaspisahkan dari struktur bahasanya. Batasan Levinson itu selengkapnya dapat dilihat pada kutipan berikut.

Pragmatics is the study of those relations between linguage and context thet are grammaticalized, or encoded in the structure of a language (levinson, 1983:9)

Berdasarkan beberapa teori di atas dapat disimpulkan bahwa pragmatik merupakan salah satu cabang ilmu linguistik yang membahas tentang segala hal yang 
berkaitan dengan struktur bahasa sebagai alat komunikasi antara penutur dan mitra tutur dan kontek bahasanya.

Austin (dalam Rusminto, 2010: 22) pertama kali mengemukakan istilah tindak tutur. Austin mengemukakan bahwa aktivitas bertutur tidak hanya terbatas pada penuturan sesuatu, tetapi juga melakukan sesuatu atas dasar tuturan itu. Pendapat Austin ini didukung oleh Searle (dalam Rusminto 2010: 22) dengan mengatakan bahwa unit terkecil komunikasi bukanlah kalimat, melainkan tindakan tertentu, seperti membuat pernyataan, pertanyaan, perintah, dan permintaan.

Berdasarkan uraian di atas dapat disimpulkan bahwa tindak tutur adalah teori yang mengkaji makna bahasa yang didasarkan pada hubungan tuturan dengan tindakan yang dilakukan oleh penutur kepada mitra tuturnya dalam berkomunikasi.

Berkenaan dengan tuturan, Austin (dalam Rusminto, 2010: 22-23) Mengklasifikasikan tindak tutur atas tiga klasifikasi, yaitu tindak tutur lokusi, tindak tutur ilokusi,dan tindak tutur perlokusi.

Searle (dalam Pattiasina, 2005: 96) mengatakan bahwa tindak ujaran ekspresif digunakan oleh pembicara bila ia ingin menyatakan keadaan psikologisnya mengenai sesuatu, misalnya, menyatakan rasa terima kasih, belasungkawa, menyampaikan ucapan selamat, memuji dan juga mengumpat. Karena tindak ujaran ekspresif menyatakan keadaan psikologis seseorang, maka pelaksanaannya pun bukan berupa perbuatan, khususnya perbuatan fisik melainkan hanya sekedar ujaran sebagai perwakilan atas keadaan seseorang atau penutur.

Wujud dari tuturan pujian merupakan bentuk verbal berupa kalimat yang diucapkan oleh seseorang untuk menyampaikan maksud agar dapat dipahami. Dari pernyataan tersebut disesuaikan dengan teori Rahardi (dalam Pattiasina 2005:76) menyatakan bahwa wujud strukturalnya merupakan realisasi maksud tindak tuturan apabila dikaitkan dengan ciri formal atau ciri strukturalnya. Dalam bahasa Indonesia tuturan secara struktural terdiri atas kalimat yakni kalimat deklaratif, kalimat interogatif, dan kalimat imperatif .

Kalimat deklaratif atau disebut kalimat (pernyataan) adalah kalimat yang isinya menginformasikan atau memberitakan menegenai sebuah informasi dalam suatu tuturan, sedangkan kalimat interogatif atau kalimat pertanyaan adalah kalimat yang isinya meminta orang untuk mendengarkan kalimat itu agar memberi jawaban atau tanggapan kepada penutur, dan kalimat imperatif atau kalimat perintah adalah kalimat yang memiliki makna meminta atau menyuruh atau memintah agar seseorang mau melakukan sesuatu yang diinginkan oleh penutur (Pattiasina, 2005: 76-77)

Fungsi pujian guru bervariasi dari satu kelas ke kelas lainnya. Ini terjadi karena latar belakang sosial dan budaya guru yang berbeda. Perbedaan ini sangat mempengaruhi perilaku guru, baik secara verbal maupun fisik. Pujian berfungsi untuk 
menyelamatkan wajah dan menyediakan lingkungan komunikasi yang baik. Fungsi pujian yang ditemukan dari temuan adalah untuk membuat penolakan tidak terlalu menyakitkan, menyampaikan perintah dan memperingatkan dengan cara yang baik, mendorong, memberi nasihat, menerima dan memberi izin.

Fungsi verbal tuturan ekspresif pujian dalam pengamatan terhadap penggunaannya di dalam interaksi sosial dapat berwujud teguran, penerimaan (mengakuan / kekuatan), perintah serta mengkritik (Pattiasina, 2005 : 56). Keempat fungsi tuturan ekspresif pujian ditemui dalam komunikasi sehari-hari antara penutur yang menyampaiakan maksud tuturannya kepada mitra tutur dengan tujuan / maksud penyampaiannya dapat dipahami dengan baik.

Iskandar dalam (Pattiasina, 2005) bahwa pujian merupakan salah satu ujaran yang bertujuan sebagai tegur sapa, misalnya mengajak beramah-tamah, berbasahbasih, dan lain-lain. Lebih lanjut dijelaskan Malinowski bahwa pengertian pujian sebagai komunikasi fatis (phatic commonication) (Ibrahim, 1993). Komunikasi fatis bertujuan membangun kontak sosial yang mengacuh pada penggunaan bahasa untuk menjalin hubungan, memelihara, serta memperlihatkan perasaan bersahabat atau solidaritas sosial.

Tindak Tutur Langsung adalah tindak tutur yang menunjukkan fungsinya dalam keadaan (tindakan) langsung dan literal (penuturan yang sesuai dengan kenyataan). Tindak tutur langsung ini dinyatakan melalui dua cara, yaitu (a) penutur yang sesuai dengan kenyataan "tuturan situasional" dan (b) penggunaan frasa verba sebagai tindak ujar. Sedangkan tindak tutur tidak langsung adalah tindak tutur yang dinyatakan dengan menggunakan bentuk lain dan tidak literal (penuturan yang tidak sesuai dengan kenyataan) dengan maksud untuk memperhalus, menghindari konflik, dan mengupayakan agar komunikasi tetap menyenangkan.

Penelitian tentang tindak tutur bukanlah hal baru yang diteliti. Ada beberapa peneliti yang sudah melakukan penelitian tentang tindak tutur, tetapi pemilihan jenis tindak tutur yang dapat dijadikan objek tentulah berbeda. Beberapa penelitian tersebut yaitu:

Dr. P.J. Pattiasina (2005) Dosen FKIP program studi Pendidikan Bahasa dan Sastra Indonesia Universitas Pattimura Ambon "Tesis" berjudul Bentuk Ekspresif Pujian Bahasa Indonesia dalam Masyarakat Tutur Ambon. Penelitian ini juga dianggap relevan dengan penelitian sekarang, karena pengkajiannya tentang tindak tutur ekspresif pujian, selain penelitian ini mengkaji tentang tindak tutur. penelitian ini juga merupakan penelitian deskriptif, karena menggunakan metode penelitian kualitatif yang tujuannya menggambarkan bentuk ekspresif pujian bahasa Indonesia dalam masyarakat tutur Ambon. Penelitian ini telah menghasilkan tiga wujud verbal tuturan pujian yaitu kalimat deklaratif (kalimat pernyataan), kalimat interogatif 
(kalimat pertanyaan) dan kalimat imperatif (kalimat perintah), kemudian 12 fungsi bentuk tuturan pujian bahasa Indonesia dalam masyarakat tutur Ambon, meliputi memperlembut penolakan, meminta, menyetujui, mengagumi, menyanjung, memperlembut kritik, membanggakan, basa-basi, memotivasi, memperhalus larangan, memperhalus teguran dan memperhalus perintah. Selain itu terdapat dua modus yang ditemukan dalam tuturan ekspresif pujian masyarakat tutur Ambon. Pertama, tindak tutur langsung dan kedua, tindak tutur tidak langsung.

Hasil penelitian ini kemudian dijadikan sebagai alat bantu dalam menarik kesimpulan. Penelitian ini dianggap relevan karena meneliti tentang tindak tutur imperatif juga merupakan penelitian deskriptif dengan metode penelitian kualitatif, yang fokus kajiannya ada pada masyarakat tutur Ambon dengan tinjauan pragmatik. Sementara peneliti sekarang mengkaji tentang tindak tutur pujian dengan objek penelitiannya ada pada siswa kelas XI SMA Negeri 1 Tutuk Tolu. Oleh karena itu hasil yang nantinya diperoleh juga akan berbeda dengan penelitian sebelumnya.

\section{B. METODE PENELITIAN}

Di dalam penelitian ini, menggunakan metode penelitian kualitatif deskriptif. Metode ini digunakan untuk mendeskripsikan wujud verbal, fungsi dan modus tindak tutur pujian pada siswa kelas XI dan guru SMA Negeri 1 Tutuk Tolu. Teknik yang dipakai dalam penelitian ini adalah teknik observasi, rekaman, wawancara, pendokumentasian dan catatan lapangan. Penelitian ini menggunakan teknik analisis data model alir melalui beberapa tahap, yaitu pengumpulan data, reduksi data, penyajian data, dan kesimpulan.

\section{PEMBAHASAN}

Wujud verbal tuturan pujian yang ditemukan dalam penelitian ini adalah sebagai berikut;

1. Kalimat Deklaratif (pernyataan)

Contoh(1), Konteks; Siswa kelas XI diperintahkan memasang lonceng sekolah di depan ruang guru.

Pak Koce : "Bagaimana su beres ?"

(BI) : Bagaimana, suda selesai?

Aju :"Suda pa guru”

(BI) : Sudah pak guru.

Pak Koce : (melihat hasil kerja siswa), “Bagus Makasi lae”(BMA)

(BI) : Bagus terima kasih. ( CTL 01)

Tuturan pujian "Bagus Makasi lae" dituturkan pada saat siswa kelas XI diperintahkan memasang lonceng sekolah di depan ruang guru. Tuturan pujian ini 
dituturkan dalam wujud pernyataan dengan tujuan menyampaikan bahwa apa yang dilakukan siswa saat itu sesuai dengan apa yang diinginkan pak koce.

Contoh(2), Konteks: Ibu Santi menegur siswa yang sedang berkaca di jendela kelas saat jam istirahat

Ibu Santi: “Kau baban lo” (BG) (teguran)

(BI ) : Kamu sudah cantik.(CTL 15)

Tuturan pujian “Kau baban lo” dituturkan pada saat Ibu Santi menegur siswa yang sedang berkaca di jendela kelas saat jam istirahat. Tuturan ini dituturkan secara langsung dengan wujud pernyataan dengan tujuan menyampaikan kepada Ratna bahwa tanpa berkaca pun kamu tetap cantik dengan seragam sekolah.

2. Kalimat Interogatif (Pertanyaan)

Contoh(1)

Konteks; Pak Idris Rumau guru bahasa Indonesia memulai pembelajaran dengan kegiatan apersepsi.

Pak Idris: " Siapa yang bisa menjelaskan tentang bagaiamana menulis sebuah laporan?

Siswa 1: "Saya akan mencoba menjawab (siswa menjelaskan)

Pak Idris:“Ya, benar. Ada yang bisa memberikan jawaban yang lain ?'(CTL 07)

Tuturan pujian "Ya, benar. Ada yang bisa memberikan jawaban yang lain?" dituturkan pada saat Pak Idris Rumau guru Bahasa Indonesia memulai pembelajaran dengan kegiatan apersepsi. Tuturan ini dituturkan dalam wujud pertanyaan dengan tujuan Pak Idris ingin mendengarkan penjelasan yang berbeda selain penjelasan yang disampaikan oleh siswa 1 .

Contoh(2)

Konteks; Pak Epen mencubit telinga siswa kelas XI di depan kelas karena terlambat masuk sekolah.

Pak Epen: "Besok terlambat lae la dapa cubit ulang"

(BI): "Besok terlambat lagi, supaya dapat cubit lagi"

Siswa : "Seng pak" (sambil memegang kuping)

(BI) : " Tidak pak"

Pak Epen : "Sadap to?"(BMA)

(BI): "Enak kan?

Siswa : (tesenyum) (CTL 02)

Tuturan pujian "Sadap to?" dituturkan pada saat Pak Epen mencubit telinga siswa kelas XI di depan kelas karena terlambat masuk sekolah. Tuturan tersebut dituturkan dengan wujud pertanyaan dengan maksud yang berbeda bahwa dengan hukuman itu Pak Epen berharap untuk tidak lagi mengulangi kesalahan yang sama. 
3. Kalimat Imperatif (perintah)

Contoh(1)

Konteks : Ibu Ayu mempersiapkan kelas dan siswa sebelum belajar

Ibu Ayu: "Laki-laki gaga di balakang mari duduk di depan sini" (MBA) ( tuturan langsung )

(BI) : Laki-laki tampan yang di belakang, mari duduk di depan. (CTL 10)

Tuturan pujian "Laki-laki gaga di balakang mari duduk di depan sini" dituturkan pada saat Ibu Ayu mempersiapkan kelas dan siswa sebelum belajar. Tuturan tersebut dituturkan dengan wujud imperatif (perintah) dengan tujuan memerintahkan kepada siswa yang hobinya duduk dibelakang agar mau menempati tempat duduk yang kosong di depan .

Contoh(2)

Konteks : Ibu Santi mengontrol setiap kelas sebelum masuk kelas.

Ibu Santi: "Lia sana, kelas IPS dong pung pung bunga pagar subur tu"(BMA) (tuturan langsung)

(BI) : "Lihat di sana, Bunga pagar milik kelas IPS terlihat subur" (CTL 21)

Tuturan pujian "Lia sana, kelas IPS dong pung pung bunga pagar subur tu" dituturkan pada saat Ibu Santi mengontrol setiap kelas sebelum masuk ke ruang kelas. Tuturan tersebut dituturkan dengan wujud imperatif (perintah) dengan tujuan guru memerintahkan siswa kelas XI untuk melihat ke halaman depan kelas X dengan tanaman bunga yang subur dan berharap agar kelas XI mau merapikan tanaman bunga pagar di depan kelas mereka.

Fungsi Verbal Tuturan Pujian

a. Fungsi Penerimaan

Penerimaan (pengakuan/kekuatan) adalah suatu tuturan yang bermaksud untuk menerima sesuatu, mengakui setiap sesuatu yang baik, juga memberi kekuatan hingga sesuatu itu dapat diterima sesuai dengan keinginan penutur. Dalam proses penelitian di SMA Negeri 1 Tutuk Tolu, telah ditemukan tuturan yang memiliki fungsi penerimaan (pengakuan/kekuatan). Di bawah ini merupakan contoh tuturan dengan fungsi penerimaan (pengakuan/kekuatan) yang ditemukan di SMA Negeri 1 Tutuk Tolu adalah sebagai berikut:

Contoh(2), Konteks; Pak Najam memperhatikan kerapian siswa kelas XI IPA2 sebelum pelajaran dimulai.

Pak Najam: "Jafar".

Jafar : "Ya pak guru"

Pak Najam: "Coba kamu berdiri,"

Jafar : (Berdiri) .

Pak Najam:"Saya mau melihat penampilan seperti ini untuk semua siswa lakilaki dikelas ini. Jafar, rambut kamu rapi ya, saya suka." (CTL 06). 
Tindak tutur pujian "Jafar, rambut kamu rapi ya, saya suka". Tindak tutur ini terjadi sebelum pelajaran dimulai, ketika pak Najam memperhatikan setiap

penampilan siswa di dalam kelas. Tuturan tersebut memiliki fungsi penerimaan, karena kalimat pujian ini bermakna mengakui tindakan Jafar yang telah merapikan penampilan dan gaya rambutnya sesuai dengan keinginan semua guru, tanpa diperinta. Jika mengakui kerapian Jafar maka kalimat tersebut berterimah.

Contoh(5), Konteks; Kegiatan praktek permainan bola besar di lapangan untuk siswa kelas XI IPA 1.

Pak Hamid : "Yus, mari ikut saya"

Yusri : "Siap Pak"

Pak Hamid :"Kamu mengontrol Bola dengan sangat baik, itu bagus dan pertahankan "(CTL 13)

Tindak tutur pujian "Kamu mengontrol Bola dengan sangat baik, itu bagus dan pertahankan” . tindak tutur ini terjadi ketika pak Hamid memberikan komentar kepada siswa kelas XI IPA1 dalam kegiatan praktek permainan bola kaki di lapangan. Tuturan tersebut memiliki fungsi penerimaan, karena jika dilihat dari kalimat pernyataan bahwa tuturan tersebut mengandung makna bahwa Yusri memang melakukan kegiatan praktek mengontrol bola dengan sangat baik, sesuai dengan apa yang diharapkan Pak Hamid, sehingga dapat dikatakan berterima.

b. Fungsi Teguran

Tindak tutur pujian wujud teguran adalah tuturan yang di sampaikan penutur dengan maksud menegur, atau ingin menyampaikan sesuatu kepada mitra tutur ketika mengagumi sesuatu, atau bisa saja menegur ketika mitra tutur melakukan sebuah kesalahan namun penutur menyampaikan atau menegur dengan teguran yang bersifat menyanjung. Dalam proses penelitian di SMA Negeri 1 Tutuk Tolu, telah ditemukan tuturan dari wujud tindak tutur pujian kekuatan. Di bawah ini merupakan wujud tindak tutur pujian pengakuan yang ditemukan di SMA Negeri 1 Tutuk Tolu.

Contoh (1), Konteks; di depan kelas XI IPS Hayati bertanya kepada Salma tentang sisah uang jajan untuk jam kedua.

Hayati : "Sabantar katong jadi pi makan nasi kuning to?

(BI): "Sebentar kita jadi pergi makan nasi kuning kan?

Salma : "Kayanya seng jadi ka apa, beta pung uang tinggal Rp.2000"

(BI): "Sepertinya tidak jadi, uang saya tersisa Rp.2000"

Hayati : "Kau bei gaga waluk" (BG)

BI: "kamu melakukannya dengan sangat baik." (CTL 11)

Tindak tutur pujian "Kau bei gaga waluk ". tuturan ini terjadi ketika jam istirahat berlangsung dan dituturkan dengan menggunakan bahasa Geser. Hayati bertanya kepada Salma teman sekelasnya yang juga sahabat dekatnya tentang sisa 
Tindak Tutur Pujin Siswa Kelas XI SMA Negeri 1 Tutuk Tolu

uang jajanan untuk jam kedua, karena di awal masuk sekolah mereka sudah berjanji mau membeli nasi kuning, tetapi Salma menghabiskan uang jajannya di jam pertama dan tidak menepati janjinya. Tuturan tersebut memiliki fungsi teguran karena tindakan yang dilakukan Salma sebelum masukn kelas tidak sesuai dengan tindakannya setelah jam istirahat.

Contoh (2), Konteks; Pak Epen mencubit telinga siswa kelas XI di depan kelas karena terlambat masuk sekolah.

Pak Epen: "Besok terlambat lae la dapa cubit ulang"

(BI): "Besok terlambat lagi, supaya dicubit lagi"

Siswa : "Seng Pak" (sambil memegang kuping)

(BI) : " Tidak pak"

Pak Epen: "Sadap to?"(BMA)

(BI): "Enak kan ?

Siswa : (tesenyum) (CTL 02)

Tindak tutur pujian "Sadap to ?". tuturan ini terjadi ketika pak Epen mencubit telinga siswa di depan kelas XI IPA(1) karena terlambat masuk sekolah. Tuturan tersebut memiliki fungsi teguran, sebab mengandung maksud menegur siswa yang terlambat masuk kelas dengan tindakan mencubit kuping siswa sebagai teguran dan berharap siswa tersebut tidak terlambat lagi.

c. Fungsi Perintah

Tindak tutur pujian fungsi perintah tuturan yang disampaikan dengan maksud seseorang dapat melakukan sesuatu. Dalam proses penelitian di SMA Negeri 1 Tutuk Tolu, telah ditemukan tuturan dengan fungsi tindak tutur pujian dalam bentuk perintah. Di bawah ini merupakan wujud tindak tutur pujian perintah yang ditemukan di SMA Negeri 1 Tutuk Tolu.

Contoh (1), Konteks : Ibu Ayu mempersiapkan kelas dan siswa sebelum belajar

Ibu Ayu: "Laki-laki gaga di balakang mari duduk di depan sini"(BMA)

(BI) : Laki-laki tampan yang di belakang, mari duduk di depan. (CTL 10)

Tindak tutur pujian "Laki-laki gaga di balakang mari duduk di depan sini ". tuturan ini terjadi ketika ibu Ayu menyiapkan siswa dan kelas sebelum pembelajaran di mulai dan dituturkan menggunakan bahasa melayu Ambon. Tuturan tersebut memiliki sifat memerintah dengan maksud memberi perintah pada siswa laki-laki yang ditunjuk agar mau berpinda tempat.

Contoh (2), Konteks; Ibu Santi mengontrol setiap kelas sebelum masuk kelas.

Ibu Santi: "Lia sana, kelas IPS dong pung pung bunga pagar subur tu "(BMA)

(BI) : Lihat di sana, Bunga pagar milik kelas IPS terlihat subur. (CTL 21)

Tindak tutur pujian "Lia sana, kelas IPS dong pung pung bunga pagar subur tu ". Tindak tutur ini terjadi ketika ibu Santi mengontrol setiap setiap kelas sebelum 
masuk menerima pelajaran, di depan kelas XI IPA1 ibu Santi melihat tanaman bunga pagar yang tidak tertata rapi dan berhamburan. Tuturan tersebut memiliki fungsi memerintah karena makna dari tuturan pujian tersebut adalah penutur ingin menyuruh siswa dapat merapikan tanaman tersebut agar tidak berhamburan dan terlihat rapi.

d. Fungsi Kritikan

Tindak tutur pujian fungsi kritikan adalah tuturan yang disampaikan penutur dengan maksud memberikan masukan dengan tujuan bahwa mitra tutur dapat melakukan sesuatu dengan baik. Dalam proses penelitian di SMA Negeri 1 Tutuk Tolu, telah ditemukan tuturan dari wujud tindak tutur pujian kritikan. Di bawah ini merupakan wujud tindak tutur pujian kritikan yang ditemukan di SMA Negeri 1 Tutuk Tolu.

Contoh(1), Konteks : Ibu Santi menyiapakan siswa dan kelas sebelum belajar.

Ibu Santi: "di kelas $\mathbf{X}$ sana, ketika guru masuk mengajar itu papan tulis sudah bersih" . (CTL 08)

Tindak tutur pujian dalam bentuk kritikan "di kelas $\mathbf{X}$ sana, ketika guru masuk mengajar itu papan tulis suda bersih" . tuturan itu terjadi ketika ibu Santi sedang menyiapakan siswa dan kelas sebelum memulai pembelajaran. Tututan pujian tersebut memiliki fungsi kritikan, karena tindakan kebiasaan siswa kelas XI IPA2 yang tidak menghapus papan tulis sebelum disuruh, sehingga tuturan tersebut dituturkan dengan maksud mengkritik dengan memuji kelas yang lain.

Contoh (5), Konteks : Ahmad berkomentar setelah mendengar Zainudin bernyanyi.

Zainudin: (bernyanyi)

Ahmad : "We jang lae, kau pung suara su bagus, beso katong dua pi jual ikan kau yang panggil, pasti laku”(BMA)

(BI): Cukup. Suara kamu sudah merdu, besok kita berdua pergi jualan ikan, kamu yang berteriak pasti laku. (CTL 29)

Tindak tutur pujian "We jang lae, kau pung suara su bagus, beso katong dua pi jual ikan kau yang panggil, pasti laku”. Tuturan tersebut terjadi ketika Ahmad mendengarkan Zainudin bernyanyi, tuturan ini memiliki fungsi kritikan karena tindakan Zainudin bernyanyi tidak nyaman didengar oleh mitra tutur, sehingga Ahmad ingin mengatakan bahwa suara Zainudin sangat jelek sekali dan memintanya agar mengeluarkan tuturan tersebut untuk meminta Zainudin berhenti bernyanyi.

\section{Kelangsungan dan Ketidaklangsungan Tuturan pujian}

Untuk mengetahui kelangsungan dan ketidaklangsungan pada siswa dan Guru SMA Negeri 1 Tutuk Tolu, Kecamatan Tutuk Tolu, Kabupaten Seram Bagian Timur sesuai dengan hasil penelitian adalah sebagai berikut :

1. Tindak Tutur Langsung

Contoh(9), Konteks; Guru menanggapi presentasi dari kelompok 3 . 
Tuturan Langsung :

Ibu Nisa: “ Baik, sangat luar biasa presentasiny a.” (DRK 01)

Tindak Tutur ini dituturkan pada saat siswa mempresentasikan tugas kelompoknya dengan baik. Tuturan tersebut dituturkan pada saat siswa mempresentasikan tugas kelompoknya dengan baik. Tuturan tersebut dituturkan menggunakan tindak tutur langsung dengan maksud bahwa memang benar presentasi dari kelompok 3 sangat luar biasa, sebab semua kelompok bekerja dengan baik. Tuturan itu juag dituturkan sebagai respon positif dan juga sebagai kekuatan untuk kelompok lain agar lebih berani lagi untuk tugas-tugas presentasi selanjunya.

Contoh (2), Konteks : Ibu Zainab guru Agama Islam menampilkan salah satu potongan surah $\mathrm{Al}$ Maidah ayat 3 dan siswa diperintahkan untuk menjelaskan maksud dari ayat tersebut.

Ibu Zainab: "Siapa yang bisa menjelaskan kepada kita semua tentang ayat yang suda dituliskan di depan."

Aida : : "Saya ibu (mengajukan tangan, dn menjelaskan)

Ibu Zainab:"Luar biasa, siapa lagi yang mau menjelaskan tentang ayat ini" (CTL 26)

Tindak Tutur di atas terjadi ketika Ibu Zainab guru agama islam menampilkan salah satu potongan surah Al-Maidah ayat 3 dan siswa diperintahkan untuk menjelaskan maksud dari ayat tersebut. Tuturan ini di tuturkan karena Aida menjelaskan potongan ayat tersebut dengan baik meskipun belum tepat. Tuturan pujian tersebut menggunakan tindak tutur langsung dengan maksud Ibu Zainab senang jika siswa memberanikan diri untuk menjawab setiap pertanyaan yang ditanyakan guru. Tuturan tersebut juga dituturkan untuk memancing siswa lain agar mau menjawab pertanyaan meskipun jawaban itu belum sempurna.

2. Tindak Tutur Tidak Langsung

contoh(1), Konteks; Ibu Nisa guru bahasa inggris menanyakan sekertaris kelas XI IPA1

Ibu Nisa : "Siapa yang menjadi sekertaris di kelas ini "?

Siswa : "Belum ada sekertaris ibu."

Ibu Nisa : "Belum ditunjuk?"

Siswa : "Iya ibu"

Ibu Nisa :"Bagus, sudah berapa lama kalian sekolah ?"

Siswa : "Ini sudah minggu ke dua ibu". (DRK 03)

Tindak tutur tersebut terjadi ketika Ibu Nisa menanyakan sekertaris kelas XI IPA1. Tuturan tersebut dituturkan pada saat Ibu Nisa ingin mengaitkan materi tentang tawaran dengan tawaran untuk menjadi sekertaris di kelas, untuk menjawab pertanyaan Ibu Nisa, siswa menjawab bahwa mereka belum memilih sekertaris kelas dan yang lainnya. Oleh karena itu Ibu Nisa menuturkan tuturan "Bagus, sudah 
berapa lama kalian sekolah ?". Tuturan tersebut dituturkan dengan tuturan tidak langsung dengan maksud mengatakan kepada siswa bahwa sudah seharusnya mereka memiliki sekertaris, ketua kelas dan lainnya. Penutur juga berharap agar siswa tidak mengulangi pada semester berikutnya.

Contoh(2); Konteks; di depan kelas XI IPS Hayati bertanya kepada Salma tentang sisah uang jajan untuk jam kedua.

Hayati : "Sabantar katong jadi pi makan nasi kuning to?

(BI): "Sebentar kita jadi pergi makan nasi kuning kan?

Salma : "Kayanya seng jadi ka apa, beta pung uang tinggal 2000”

(BI) : "Sepertinya tidak jadi, uang saya tersisa 2000"

Hayati : "Kau bei gaga waluk (BG))

BI: Kamu melakukannya dengan sangat baik. (CTL 11)

Tuturan ini terjadi ketika jam istirahat berlangsung. Hayati bertyanya kepada Salma teman sekelasnya yang juga sahabat dekatnya tentang sisah uang jajanan untuk jam kedua, karena di awal masuk sekolah mereka sudah berjanji mau membeli nasi kuning , tetapi Salma menghabiskan uang jajannya di jam pertama dan tidak menepati janjinya. Tuturan tersebut dituturkan dengan tuturan tidak langsung, karena Hayati sebenarnya ingin mengatakan kepada Salma bahwa yang di lakukan Salma itu terlalu boros dan tidak menepati janji.

\section{KESIMPULAN}

Berdasarkan hasil penelitian yang telah dipaparkan pada bab IV dapat disimpulkan sebagai berikut:

Tuturan pujian yang ditemukan menggunakan tiga bahasa yakni Bahasa Indonesia yang ditemukan dalam proses pembelajran, kemudian Bahasa Melayu Ambon dan Bahasa Geser yang ditemukan dalam keadaan santai baik di dalam kelas maupun di luar kelas.

wujud verbal tuturan pujian yang didapatkan adalah wujud deklaratif atau kalimat pernyataan sebanyak 31 (tiga puluh satu) data, wujud interogatif atau kalimat tanya sebanyak 6 (enam) data, dan kalimat imperatif atau kalimat perintah sebanyak 2 (dua) data. Wujud tuturan pujian tersebut yang lebih dominan adalah wujud pernyataan. Pada umumnya, seseorang senang karena dipuji dari sebuah pernyataan. Oleh karena itu siswa dan guru SMA Negeri 1 Tutuk Tolu biasanya mengekspresikan sesuatu yang dianggap menghibur hatinya melalui sebuah pernyataan.

Fungsi verbal yang ditemukan dalam penelitian ini diantaranya fungsi penerimaa (pengakuan / kekuatan) sebanyak 27 (dua puluh tujuh) data, fungsi teguran sebanyak 5 (lima) data, sedangkan fungsi perintah sebanyak 2 (dua) data, dan fungsi kritikan 
sebanyak 6 (enam) data tuturan pujian. Untuk fungsi, yang lebih dominan adalah fungsi penerimaan karena pada dasaranya memuji berarti menilai sesuatu yang positif, yang tujuannya adalah memberikan kekuatan dan sebagai bentuk motivasi. Dengan bentuk penerimaan, siswa mendapatkan pengakuan/kekuatan baik dari guru maupun dari siswa yang lain. Selain itu juga dapat menjalin hubungan kekerabatan antara guru dengan siswa, juga siswa dengan siswa yang lain.

Kelangsungan dan ketidaklangsungan yang digunakan dalam menuturkan tuturan pujian di antaranya tuturan pujian dengan tindak tutur langsung sebanyak 28 (dua puluh delapan) data, dan tindak tutur tidak langsung 22 (dua puluh dua) data. Antara tindak tutur langsung dan tindak tutur tidak langsung tuturan yang lebih dominan digunakan adalah tindak tutur langsung. Tuturan pujian digunakan dengan tuturan langsung tidak menghambat bagi penutur yang menginginkan bahwa tuturannnya dapat dipahami oleh mitra tutur tanpa harus berpikir panjang.

\section{DAFTAR PUSTAKA}

Chaer, Abdul dan Agustina Laonie. 2014. Sosiolinguistik Perkenalan Awal. Jakarta : Rineka Cipta

Ibrahim, Syukur Abdul. 1993. Kajian Tindak Tutur. Surabaya. Usaha Nasional

Leuwol, Welda. 2015. "Tindak Tutur Imperatif Guru Play Group Pelangi Asih Kayu Tiga di Kota Ambon”. Skripsi pada Program Studi Pendidikan Bahasa dan Sastra Indonesia Universitas Pattimura Ambon.

Moleong. Lexy J. 2012. Metodelogi Penelitian Kualitatif. Bandung: Remaja Rosdakarya.

Pattiasina, P.J. 2005. "Bentuk Ekspresif Pujian Bahasa Indonesia dalam Masyarakat Tuturan Ambon . Malang: Universitas Negeri Malang” Tesis(Tesis tidak diterbitkan)

Pattiasina, Petrus Jacob, Djoko Saryono, Maryaeni, Mudjianto. “Teacher's Act Of Praise in the Classroom. Volume 6 Issue 5, May 2017, hal.13151319.Doi:10.21275/ART20173449. Diakses dari http: //www.ijsr.net. Diunduh tanggal 3 maret 2020.

Rahardi, Kunjana. 2005. Berkenalan dengan Ilmu Bahasa Pragmatik. Malang: Dioma.

Rusminto, Nurlaksana Eko. 2010. Memahami Bahasa Anak-Anak. Bandar Lampung: Universitas Lampung. 